UDC 316.4: (410)

DOI https://doi.org/10.32841/2707-0018.2019.17.14

Levchenko A. V., Candidate of Philosophy, Associate Professor of the Department of Philosophy and Political Science of the Khmelnytsky National University

\title{
POLITICAL COMMUNICATION IN THE CONTEXT OF CONTEMPORARY DISCOURSE
}

\begin{abstract}
Summary. Communication has always been an integral part of society's life, however, in the modern age the communicative processes become system-forming and lose their secondary character. Similar changes are also taking place in the political sphere, where the particular role of political communication in the process of reproduction of the political system turns out to the fore.
\end{abstract}

Political communication in a society with such characteristics becomes a decisive factor in determining its nature. There was a belief in virtually unlimited possibilities of influence of discussion on human consciousness, which led to widespread, including manipulative techniques, but at the same time facilitated the study of political communication to protect society from such influence in the future.

The development and large-scale introduction of new technologies have determined the scientific interest of researchers in a new type of society in which the mass of people lives in conditions other than those of industrialism. Among the various variants of periodization of history associated with the technological development of society, postindustrialist concepts were formed, which justified the onset of a new era following the era of industrialism. The founders of post-industrialism define the formation of modern society through the advancement of knowledge and technological advancements, appreciating science, and education. By the early $1960 \mathrm{~s}$, the methodological foundations of postindustrialism had been formed, and gradually, this concept became one of the foundations of the study of society.

The new role of communicative processes determined the scientific interest in political communication and led to the emergence of diverse approaches to its study, formed into a separate research field in which political discussion is studied as a defining element of the political system of society. In some aspects of it in particular through the prism of its interaction with actors.

In modern humanities, political communication is the subject of political science, including political theory, sociology, psychology, history, linguistics, and many other branches of knowledge.

Key words: communication, crowd, public, actor.

Formulation of the problem. Political communication in one form or another has always been an integral attribute of political life, and its conception within science began in the early twentieth century, after the First World War, when the consequences of the use of manipulative propaganda were particularly pronounced.

Analysis of recent research and publications. The scientific study of the nature of political communication begins with the beginning of the XX century. It is represented in the modern scientific community by many different types of research. In general, we can divide existing sources of political communication analysis into several groups. The first group of sources is related to the theoretical and methodological base of research: theories of mass society (the works of G. Lebon, H. Ortega-i-Gasset, G. Tard), general cybernetics (the works of N. Wiener, K. Shannon, U. Weaver ), post-industrial and information society theories (D. Bell, E. Toffler).

Another group of sources is related to the study of political communication within the framework of political and social theories. It is presented by the works of P. Bourdieu, E. Giddens, K. Deutsche, I. Hoffman, G. Bloomer, W. Lippman, N. Luhmann, Y. Habermas, M. Castels, M. McLuhan, and R. Debre. These authors cover issues of the organization of society and the political system that underlies communication processes.

The purpose of the study is to analyze the main theoretical interpretations of political communication, to study the most promising methodological approaches to its study, and to indicate the potential of their development.

The goal is realized by solving the following tasks that determine the structure and logical sequence of the study - to explore historical traditions of study and current interpretations of the phenomenon of political communication.

Outline of the main research material. One of the first political communication theorists, Harold Lasswell, identified political communication as a process that can be explored by answering the question: who reports? What is reporting? When reports? Whom? With what effect? [12, p. 10]. These questions, which reflect the notion of political communication in the early stages of its research, characterize it as a process in which the communicator transmits information to the recipient and expects some effect from its perception, that is, a technical process.

However, political communication can also be understood as crucial to the political process. K. Deutsch proposed one of the most metaphorical definitions of political communication. He compared political communication with the nerves of public administration in the system of the state information plays a decisive influence on political decision-making and citizens' behavior; accordingly, it is a universal tool in the hands of the authorities [10].

In modern political science, the definition of political communication remains unanswered. For example, the French researcher Jacques Garstle states that the phenomenon is difficult to define since it is supersaturated in content, characterized by difficulty and multidimensionality [14, p. 392]. Besides, the problem is compounded by the uncertainty of communication concepts and politics; the complexity of the phenomenon causes a variety of interpretations. Among the current definitions of political communication proposed by researchers and professional associations, we can distinguish the following groups: 
Political communication as a process with specific characteristics:

- the continuous process of information transfer and its circulation between different parts of the political system;

- the process of interaction regarding the transfer of information between politicians, the media, and the public. It goes in a downward direction - from politicians to society, upward from society to politicians, and horizontally - between politicians;

- the creation, formation, dissemination, and impact of information on the political system - domestic and international, involving states, other institutions, groups, or individuals.

Political communication as thematic communication:

- discussion of the location of public resources, public authorities, official decisions aimed at influencing society.

- all types of targeted policy communication, which includes all forms of communication used by politicians and other political players to achieve specific goals.

Political communication as a communication that uses specific methods: a political language that uses rhetorical, paralinguistic signs, and political acts.

Political communication, as communication of certain actors: the interconnection of communication and politics, including interactions between citizens, between citizens and their governments, between government officials and their governments.

Complex definitions - a process in which the language and symbols used by leaders, the media, and the public influence, unpredictably or unpredictably, the political processes, attitudes, and behavior of individuals, or influence the public policies of a nation, state, or community.

The latter definition, which is involved, is the most appropriate for this study, as it emphasizes all the essential aspects of this phenomenon: political communication is a process, not a separate action; political communication is based on language and symbols that can be used for specific action; political communication actors are elite, media and citizens; the effects generated by political communication can be both predictable and unpredictable for the communicator.

Thus, in defining political communication, one must turn to the historical and methodological prerequisites underlying the interest in information and communication.

The beginning of the XX century is characterized by two interrelated processes: the emergence of mass society, and the stage of formation of post-industrial society. Philosophical and theoretical coverage of the phenomenon of masses and mass society is presented in the works of Gustav Lebon, Jose Ortegai-Gasset, Serzh Moskovichi, the theorists of the Frankfurt School. In general, we can talk about the formed pessimistic view of the mass society and man.

G. LeBon, noting that the main feature of his modern era is the replacement of the conscious activity of individuals, the unconscious activity of the crowd suggests that the disappearance of conscious personality precedes the unification of feelings and thoughts as a result of the possible emergence of the collective soul. It does not matter whether the individuals will be in one place or separated from each other, the most necessary for the organization of the crowd - the influence of some pathogens. Since the crowd is always in a state of "anticipated attention" it is quickly ready to accept the suggestion if the feelings are pure. Presented in the form of images, suggestions can make the crowd both heroic and criminal.
Knowledge of the basic properties of the crowd, according to G. Lebon, will not allow the crowd to capture the whole society $[3$, p. 72-118].

When applying Lebanon's theory to political communication, it should be borne in mind that it is the crowd that becomes the public to which the messages of the communicators are now addressed. In this sense, knowledge of crowds and masses contributes to the effectiveness of communication. G. LeBon emphasizes the need for external stimuli, the use of sharp images that make the crowd, as compared to the individual, more inclined to believe that this is the ultimate goal of political communication.

In the works of H. Ortega-i-Gasset, the mass appears negatively. The masses appear in the political arena with their demands. Their desire to participate in politics is associated with a sense of perfection. Thus, the masses deny any opposition, the possibility of discussion, the search for truth, they accept certain statements depending on the level of their correspondence to the requests of the masses. However, the mass does not exist by itself; to regulate the direction of action requires selected minorities elites, leadership, or opposition elites. The elites, as the primary communicator, seek to provide themselves with the necessary resources, including access to the censorship of information, to master the devotion of the masses [7, p. 64].

S. Moskovichi, based on already classical studies of the phenomenon of mass society, draws general conclusions. The researcher envisages the transition not only to the era of masses but more, to the globalization of masses, to the creation of masses of world scale in the form of supranational communities living and consuming in the same way. In these circumstances, politics becomes widespread, and the cult of personality becomes the rule. At this time, the essential task of politics is to organize the masses to act by the laws of human nature. Thus, politics is a rational form of use of the irrational nature of the masses, who through the media have made it out of the crowd. Ultimately, a person ceases to belong to the public only to enter the crowd or into another audience. The media did not require the physical gathering of people to exchange views. Communication through the media contributes to the formation of public opinion, which is offered in the form of generally recognized. S. Moskovichi finds that the power of the media and the power of public opinion are identical [5].

Thus, the study of political communication began in the conditions of mass society, among the main characteristics of which are the following: suggestiveness; dependence on the subject of influence - the elite; uniformity and noncritical thinking; breaking the individual with traditional social communities; understanding the media as the primary source of political information.

Political communication in a society with such characteristics becomes a decisive factor in determining its nature. There was a belief in virtually unlimited possibilities of influence of communication on the consciousness of the person, which led to widespread, including manipulative techniques, but at the same time facilitated the study of political communication in order to protect society from such influence in the future.

Thedevelopmentandlarge-scaleintroductionofnewtechnologies have determined the scientific interest of researchers in a new type of society in which the mass of people lives in conditions other than those of industrialism. Among the various variants of periodization of history associated with the technological development of society, 
post-industrialist concepts were formed, which justified the onset of a new era following the era of industrialism. The founders of post-industrialism define the formation of a new society through the advancement of knowledge and technological advancements, appreciating science, and education. By the early 1960s, the methodological foundations of post-industrialism had been formed, and gradually, this concept became one of the foundations of the study of society.

One of the founders of the concept of post-industrialism is Daniel Bell. In his theory, post-industrial society is replacing industrial and opposing it. The post-industrial society offers opportunities for more effective management of the social organism, especially in matters of distribution of goods and protection of individual freedom of the individual. Post-industrial society, by its logic, is a meritocracy, which means a new form of access to socially relevant positions and privileges, and higher education is becoming the most important means of obtaining them. Thus, meritocracy becomes the new principle of stratification of society, and knowledge acquires a special status [1, p. 34-182].

Gradually developing the position of post-industrialism, D. Bell substantiates the emergence of an information society. He believed that the information and technological revolution would lead to a new type of society - the information or society of knowledge. One of the main characteristics of this society is its global character $[1$, p. 273]. Knowledge is a particular type of information and is theoreticalinnature, ithas asignificantimpactonall spheres of society, because it involves a new type of development of the world, which focuses not so much on practical problems as on the predominance of theory and codification of knowledge, which contributes to its practical use. The unique role of information and knowledge in the new society gives a special status of communication as a process of transfer and assimilation of knowledge and information.

The term "information society" itself appeared in Japan in the 1960s (in the works of Tadao Umesao, Eneji Masudi), although there is an opinion that the US belongs to the primacy [4], where the discussion of the peculiarities of the information society began without the use of the specific term. In the initial stages of theoretical understanding, the most essential characteristics of the information society were called the following: the development of computerization facilitates citizens' access to reliable sources of information; the share of production of information product is much higher than the share of production of material product, which becomes the driving force for the development of education and society as a whole. The onset of the information society is characterized by systematic political, technical, economic, and cultural changes.

The concept of the information society was reflected not only in theoretical developments, but its ideas also interested the politicians who transformed it into a strategy for global development. So, in 2000, on Fr. Okinawa is the leader of the G-7 countries, the Charter of the Global Information Society, was adopted. The Charter calls for closing the international information and knowledge gap. It argues that the resilience of the global information society is based on processes that foster the development of democratic values, such as the free exchange of information and knowledge, mutual tolerance and respect for the individual. The Charter emphasizes that the new information system is global, which means that it requires a global approach, the implementation of which requires close political cooperation between the countries concerned [6]. Thus, the information age has received official, international recognition and outlined new perspectives, both on the internal development of states and on international development, which envisages politically-guaranteed access to information and knowledge at the individual level. States have assumed responsibility for creating global and equitable access to information that envisages the development of a communication infrastructure responsible for the communication of communication actors.

Returning to the history of theoretical understanding of the problem, it should be noted that in addition to the concepts of "information society" and "knowledge society", which D. Bell, for example, identifies, the concept of "knowledge-based society" ("knowledgeable society" was introduced into science)"). Yes, Robert Lane proposes to view knowledge as a broad category that is relevant to all walks of life. "Knowledge-based society" he defines as a society whose members, in more detail than members of other types of societies, analyze their views on man, nature, social life; allocate essential resources to the quest for knowledge; collect, organize and interpret their knowledge depending on the goals; apply their knowledge to identify and refine goals and objectives. To support such a desire for knowledge, society must be openminded, discussions on everyday topics must be allowed, and all conditions are created to realize the desire to know more. However, a knowledge-based society assumes not only the high value of knowledge for people but also the likelihood of appreciation of that knowledge. In the field of politics, this means, first and foremost, a change in the decision-making criterion - the place of immediate political gain is the domination of professional knowledge. Thus, knowledge becomes a factor of influence on social life and a factor of destabilization of the established order even without the activity of pressure groups and without appeal to ideology [13, p. 650-651].

In general, we can say that the concept of R. Lane complements the concept of the information society and allows us to reveal the essence of the information society from a different angle. At the heart of R. Lane's views is a new status of knowledge: it is the attitude to the knowledge that determines the vector of development of a new, information-rich society whose dissemination is global [13].

In a rather pessimistic perspective, he develops the ideas of the post-industrial and information society, Alvin Toffler [8]. $\mathrm{He}$ traditionally views social development as a series of changing waves. In The Third Wave, it shows the emergence of civilization, which challenges old installations that are no longer true. Industrial society is replaced by the Second Wave; the Third Wave arrives, the centerpiece of new information that compels people to view the formed images. For the first time in the history of humanity, a new form of ownership emerges, which is intangible. During the Second Wave, the media gained enormous power. During the Third Wave, a phenomenon emerges, which Toffler calls "mass media densification", which results in audience segmentation, which results in people no longer receiving a ready-made model of reality. It is both a heavy burden of self-cognitive process and the densification of personality, which is expressed in the growth of individuality. The densification of the mass media is a reflection of a more general tendency - the densification of civilization. It envisages an increase in the amount of information that people exchange. This growth explains why society is becoming informative: "as people around us become more individualized and democratized, we are increasingly in need of information. Ultimately, individuals and organizations are constantly striving for more information, and increasing data flows are pulsing throughout the system" [8, p. 41-42]. 
Even though E. Toffler emphasizes the increase in the amount of information, unlike the theorists of the mass society, he denies global massisation and predicts further individualization, the consequences of which are manifested in the apathy of the person associated with the inability to capture "flows of information". However, in the future, individualization will lead to severe such segmentation in society that it will be necessary to unite people based on some consensus [8, p. 112-182]. Thus, E. Toffler points to a change in the role of man in an information society other than the industrial one. He sees the role of the media not in imposing a unified view on specific issues, but in the fragmentation of society by providing a variety of information that can satisfy the needs of the audience. Such an original view of the changing nature of mass society and its transformation into a democratized society may be because overmassification has the consequence of individualization, which is expressed in the problem of communication, due to the growing need for knowledge and scarcity of resources. This is in line with new trends, which express a new era, tentatively called post-postmodernity, which, however, has not yet been conceptually defined [8, p. 200-231].

Despite a large number of followers, the theories of postindustrialism and the information society are being criticized, both in individual aspects and in issues of excessive ideologization, and an overall negative impact on social life. However, changes like modern society are evident. For further research, it is necessary to identify the main aspects of these changes that have influenced the growing interest in information and communication as subjects of reflection in the social sciences.

The level of society's saturation with information is increasing, and new channels of its transmission are emerging. Information and knowledge are becoming a defining aspect of social and industrial relations: access to information becomes essential for determining a person's place in society and belonging to the elite. Information processes are global, beyond the scope of the nationstate. The nature of the perception of information by an individual change, his or her sense of self changes.

Conclusions. Thus, the general characterization of XX century society seems somewhat contradictory. On the one hand, members of the mass society are characterized as easy targets for manipulative influence, non-critical individuals, on the other - the offensive of the information society implies an increase in the level of selfreflection, the emergence of new methods of use and comprehension of information. Of course, these contradictory trends are reflected in the developed methods of studying political communication.

\section{References:}

1. Белл Д. Грядущее постиндустриальное общество. Опыт социального прогнозирования. Изд. 2-ое, испр. и доп. Москва : Academia, 2004. $788 \mathrm{c}$

2. Иноземцев В.Л. Постиндустриальный мир Даниела Белла. Даниел Белл ; Пер. с англ. под ред. В.Л. Иноземцева. Москва : Academia, 2004. $783 \mathrm{c}$

3. Лебон Г. Психология народов и масс / Пер. с фр. А.Фридмана, Э.Пименовой. 4-е изд. Москва : Академический Проект, 2016. $239 \mathrm{c}$

4. Махлуп Ф. Производство и распространение знаний в США. / Ф. Махлуп. Москва : Прогресс, 1966. 462 с.

5. Московичи С. Век толп. Исторический трактат по психологии масс / Пер. с фр. Т.П. Емельяновой. Москва : Академический проект, $2011.396 \mathrm{c}$.
6. Окинавская хартия глобального информационного общества. Дипломатический вестник. 2000. № 8. С. 59-63.

7. Восстание масс : [Сборник: Пер. с исп.] / Хосе Ортега-и-Гассет. Москва : АСТ : Ермак, 2003 (ГУП Чехов. полигр. комб.). 269 с.

8. Тоффлер Э. Третья волна. Москва : ООО «Фирма "Издатетьство ACT"», 2004. C. 6-261.

9. American Political Science Association. URL: http:// apsapolcommunication.weebly.com/ (13.12.2016).

10. Deutsch K. W. The nerves of government: Models political communication and control. New York, London : Free press CollierMacmillan, 1966.

11. International Communication Association. URL: http:// www-bcf.usc.edu/ ica/association/divisions.html\#DIVISION6(13.12.2016).

12. Lasswell $\mathrm{H}$. The structure and function of communication in society. The communication of ideas / ed. by L.Bryson. New York : The Institute of Religious and Social Studies, 1958. P. 10-26.

13. Lane R.E. The decline of politics and ideology in a Knowledgeable society. American sociological review. 1966. Vol. 31. № 5. P. 650-655.

14. Gerstlé J. Political Communication: from international institutionalization to national conquest of scientific legitimacy. The Oxford Handbook of French Politics / ed. by R. Elgie, E. Grossman, A.G. Mazur. P. 383-410.

Левченко А. В. Політична комунікація в контексті сучасного дискурсу

Анотація. Комунікація завжди була невіддільною частиною життя суспільства, однак у сучасну інформаційну епоху комунікативні процеси стають системоутворюючими і втрачають свій допоміжний характер. Подібні зміни відбуваються і в політичній сфері, де на перший план виходить особлива роль політичної комунікації в процесі відтворення політичної системи.

Опосередкованість політичної комунікації в суспільстві з такими характеристиками стає вирішальним фактором у визначенні ії характеру. 3'явилася віра в практично необмежені можливості впливу комунікації на свідомість людини, що призвело до широкого поширення маніпулятивних технік, але водночас сприяло вивченню політичної комунікації з метою захисту суспільства від подібного впливу в майбутньому.

Розвиток і широкомасштабне впровадження нових технологій визначило науковий інтерес дослідників до нового типу суспільства, в якому людина маси живе в умовах, відмінних від умов індустріалізму. Серед різних варіантів періодизації історії, пов'язаних 3 технологічним розвитком суспільства, формувались і постіндустріалістські концепції, які обгрунтовували настання нової ери, наступної за епохою індустріалізму. Основоположники постіндустріалізму визначають формування нового суспільства через прогрес знань і технологічних досягнень, високо оцінюючи науку й освіту. До початку 1960-х р. були сформовані методологічні основи постіндустріалізму, і поступово ця концепція стає одним з базисів вивчення суспільства.

Нова роль комунікативних процесів визначила науковий інтерес до політичної комунікації та сприяла виникненню різноманітних підходів до її вивчення, оформилась в окрему дослідницьку галузь, в рамках якої політична комунікація вивчається як визначальний елемент політичної системи суспільства, а в окремих її аспектах - через призму взаємодії іiі акторів. У сучасній гуманітаристиці політична комунікація $є$ предметом вивчення політичної науки, в тому числі політичної теорії, соціології, психологіï, історії, лінгвістики і безлічі інших галузей знання.

Ключові слова: комунікація, натовп, публіка, актор. 